\title{
Identification of New Sources of Resistance in Winter Wheat to Multiple Strains of Xanthomonas translucens pv. undulosa
}

T. B. Adhikari, J. M. Hansen, and S. Gurung, Department of Plant Pathology, North Dakota State University, NDSU Dept. 7660, P.O. Box 6050, Fargo, ND 58108; and J. M. Bonman, USDA-ARS, Small Grains and Potato Germplasm Research Unit, Aberdeen, ID 83210

\begin{abstract}
Adhikari, T. B., Hansen, J. M., Gurung, S., and Bonman, J. M. 2011. Identification of new sources of resistance in winter wheat to multiple strains of Xanthomonas translucens pv. undulosa. Plant Dis. 95:582-588.

Bacterial leaf streak (BLS), caused by Xanthomonas translucens pv. undulosa, has re-emerged as an important disease of wheat (Triticum aestivum) in the United States. Planting resistant varieties is the best approach to manage BLS in the absence of effective bactericides. However, most of the wheat varieties currently grown in the Upper Midwest of the United States appeared to be susceptible to BLS. From the core subset of the USDA National Small Grain Collection (NSGC), a set of 605 winter wheat accessions of diverse origin and improvement status were initially inoculated with a virulent strain BLSW16 of $X$. translucens pv. undulosa from Casselton, ND on the flag leaf of each plant in a greenhouse. Disease reactions were assessed between 7 and 10 days after infiltration using a 0 to 6 rating scale, where $\leq 2.0$ was considered resistant and $>2.1$ was considered susceptible. Resistance varied with geographic origin and was significantly $(P \leq$ $0.05)$ more frequent in accessions from North America compared to accessions from northern, eastern, and southern Europe and from

south-central Asia. About $8.3 \%$ of accessions tested were resistant, and accessions with an improvement status of "cultivar" were significantly more likely to be resistant than were accessions classified as either landraces or breeding lines. Forty-two of the accessions exhibiting resistance in response to the strain BLSW16 in the first screening test were retested utilizing each of the two additional strains (BLS Cr25 and BLS Lb74 of $X$. translucens pv. undulosa) collected from Carrington and Lisbon, respectively. Nonparametric data analysis revealed 35 accessions were resistant, one accession, PI 266860, was susceptible to both strains, and six accessions showed differential responses. The majority of the BLS-resistant accessions also were resistant to at least one other important wheat disease based on the Germplasm Resources Information Network (GRIN) data. These results suggest that diverse and novel sources of resistance to BLS identified in this study can be utilized in winter wheat breeding programs.
\end{abstract}

Bacterial leaf streak (BLS), caused by Xanthomonas translucens pv. undulosa (3), is an important disease of wheat (Triticum aestivum L.) worldwide. The disease was first reported in 1919 (24). The early disease symptoms on the leaves are characterized by translucent water-soaked streaks that are associated with bacterial exudates (7). At the early milk to soft dough stage (Zadok's DC 77-83) (29), black chaff develops as dark purple to black blotches on the glumes $(4,24)$. During the 2008-2009 seasons, five locations (Carrington, Casselton, Fargo, Lisbon, and Prosper) and 20 wheat fields in Casselton, Fargo, and Prosper in North Dakota were surveyed, and an average $80 \%$ BLS incidence was observed (T. B. Adhikari and S. Gurung, unpublished data). The infected wheat plants were stunted and chlorotic (7).

Traditionally, BLS has been managed by treating seeds with hot water and mercury or copper fungicides (11-13); however, these methods are insufficient to meet current safety and/or efficacy standards. Although warm and humid environments are conducive for disease progression, the bacterium cannot over-summer in crop debris or in soil (19). The disease is mainly seedborne (13) and potentially transmitted through wheat germplasm exchange (1113). Yield losses of 30 to $40 \%$ due to this disease have been reported from Idaho (12).

Winter wheat cultivation has gradually expanded in the Upper Midwest region of the United States, particularly in North Dakota and Minnesota (28). Anecdotal evidence in North Dakota and neighboring states suggests that BLS has re-emerged as a potential threat to both winter and spring wheat. Recent BLS epidemics

Corresponding author: T. B. Adhikari, E-mail: tika.adhikari@ndsu.edu

Accepted for publication 1 February 2011.

doi:10.1094/PDIS-10-10-0760

(C) 2011 The American Phytopathological Society could be related to unusually high rainfall and high humidity, to possible changes in the bacterial populations, and to planting recently released wheat varieties that are susceptible to the disease. In a preliminary study, none of the commercially grown wheat varieties in North Dakota were resistant to BLS (1). Additionally, the impact of BLS on winter wheat appeared to be more severe than on spring wheat (T. B. Adhikari and M. Mergoum, unpublished data). This situation prompted us to search for resistance to BLS in winter wheat. Compared to synthetic and diploid wheat, we hypothesize that some hexaploid wheat landraces could have good agronomic adaptation and resistance to BLS and other foliar diseases of importance in the region. The main objective of this study was to identify novel sources of resistance to BLS among winter accessions in the USDA-ARS National Small Grains Collection (NSGC).

\section{Materials and Methods}

Selection of winter wheat accessions. The NSGC core subset represents $10 \%$ of the total collection and was chosen to maximize diversity based on geographic origin. There are 1,415 winter habit accessions in the core subset, and from this group 605 were randomly selected for testing. These included accessions of various categories which the Germplasm Resources Information Network (GRIN) refers to as "improvement status", i.e., breeding lines, released cultivars, cultivated accessions (where it is uncertain if the accession is a landrace or a cultivar), and landraces, which were developed in antiquity through farmer selection and natural selection (2). Nearly all of the selected accessions originated from 11 geographic "macroregions" based on the United Nations designations for World macroregions (27).

Planting of wheat accessions. Plastic cones $(3.8 \mathrm{~cm}$ in diameter and $20 \mathrm{~cm}$ long) (Stuewe and Sons, Inc., Tangent, OR) were filled with Fison sunshine mix \#1 (Fison Horticulture, Vancouver, BC) in the greenhouse. Three seeds of each accession were planted in a cone, and each accession was planted in three cones. The seedlings 
were supplied with $2.5 \mathrm{~g}$ of multicote slow release commercial fertilizer (14-14-16, N-P-K, Sungro Horticulture Distribution Inc., Bellevue, WA) at planting.

To evaluate resistance to BLS, the 605 accessions were arranged in a randomized complete block design (RCBD) with three replications. Each treatment consisted of three plants per replication (total of nine plants per accession). Each cone was considered an experimental unit, and the flag leaf of each plant was regarded as a sampling unit. Greenhouse temperatures were maintained at 24 to $28^{\circ} \mathrm{C}$ with $16 \mathrm{~h}$ of supplemental light provided by $400 \mathrm{~W}$ Lucalox LU400 sodium vapor lamps (General Electric Co., Cleveland, OH) until disease scoring. All experiments were conducted at North Dakota State University (NDSU), Fargo, 26 June 2009 through May 2010.

Inoculum preparation. Based on our preliminary results (1), a highly virulent strain, BLSW16, of X. translucens pv. undulosa from Casselton $\left(46^{\circ} 54^{\prime} \mathrm{N}, 97^{\circ} 12^{\prime} \mathrm{W}, 282 \mathrm{~m}\right.$ asl) was selected to evaluate resistance in winter wheat in this study. The bacterial strain (stored in $30 \%$ glycerol at $-80^{\circ} \mathrm{C}$ ) was revived on peptone sucrose agar (PSA) (20) plates. The plates were incubated at $28^{\circ} \mathrm{C}$ for $72 \mathrm{~h}$. The bacterial cells were scraped with a wire-loop, and inoculum was prepared by suspending bacterial cells for 2 to $3 \mathrm{~min}$ in $20 \mathrm{ml}$ of sterile deionized water per plate. The bacterial suspension was adjusted to an optical density of 0.2 at $590 \mathrm{~nm}$ using a spectrophotometer prior to inoculation, and approximately $1 \times 10^{7}$ $\mathrm{CFU} / \mathrm{ml}$ were counted by dilution plating after inoculation. The inoculum was transferred to a glass flask, placed on ice, and brought to the greenhouse for inoculation.

Plant inoculation. For each accession, the adaxial surface of a fully expanded flag leaf was infiltrated using a disposable syringe without a needle (18). Approximately 10 to $15 \mu \mathrm{l}$ of the bacterial cell suspension was gently infiltrated into the middle of the flag leaf of each plant. In each flag leaf, only one area was infiltrated with bacterial cells, and distribution of bacterial cells within the infiltrated area on the flag leaf was uniform. The sizes of the infiltrated areas ranged from 0.2 to $0.4 \mathrm{~cm}^{2}$, and they were marked by a nontoxic permanent marker on both ends. The plants were placed in trays of water and left on the bench in the greenhouse.

Disease assessment. Disease reactions within the infiltrated areas on flag leaves were visually estimated between 7 and 10 days after infiltration using a 0 to 6 rating scale (16), where $0=$ no visible symptoms, $1=$ chlorosis without water-soaked lesions, $2=$ water-soaking less than $10 \%, 3=$ water-soaking 10 to $30 \%, 4=$ water-soaking 31 to $70 \%, 5=$ water-soaking 71 to $100 \%$, and $6=$ water-soaking extending beyond the infiltrated area. Disease scores of 0 to 2 (or less than $10 \%$ water-soaking within the infiltrated areas) were considered resistant (R) (26), and 2.1 to 6 (or greater than $10 \%$ water-soaking) were regarded as susceptible (S) reactions. Wheat breeding line ND495 (1) and cultivar Magnum (17) served as susceptible (positive control) and resistant (negative control) check, respectively.

Retesting 42 resistant accessions against the two additional bacterial strains. A subset of the 50 accessions exhibited resistance to strain BLSW16 in the first screening test, and 42 resistant accessions were randomly selected (Table 1) to retest further against the two additional bacterial strains. Based on initial pathogenicity tests, two strains (BLS Cr25 and BLS Lb74 of $X$. translucens pv. undulosa) collected from Carrington $\left(47^{\circ} 27^{\prime} \mathrm{N}\right.$, $99^{\circ} 7^{\prime} \mathrm{W}, 464 \mathrm{~m}$ asl $)$ and Lisbon $\left(46^{\circ} 26^{\prime} \mathrm{N}, 97^{\circ} 41^{\prime} \mathrm{W}, 332 \mathrm{~m}\right.$ asl), North Dakota, were selected, and the inoculations repeated with each of the two additional strains on the 42 accessions. Carrington is located in Foster County, while Lisbon is in Ransom County, and these two locations are approximately $204 \mathrm{~km}$ apart. All plant growing conditions, inoculum preparation, inoculation, and disease scoring were the same as described above. The experiments were conducted in 2010. Winter wheat accessions were arranged in a RCBD with three replications. The experiment was repeated a second time with each of the two additional strains of $X$. translucens pv. undulosa on separate benches in the greenhouse. Each cone was considered an experimental unit. Flag leaves of the nine plants per accession were rated in each experiment for each strain. In each experiment, replications were regarded as a random effect and wheat accessions were considered a fixed effect.

Statistical analysis. Disease reactions of the nine infiltrated areas on flag leaves (one site on each flag leaf) of each accession were averaged. To examine the presence or absence of association between region of origin and BLS resistance, country of origin of each accession was classified geographically according to the United Nations designations for World macroregions (27). Nonoverlap of the $95 \%$ binomial confidence intervals was used to determine significant differences between geographic regions and percent resistant accessions. Association between BLS resistance and accessions improvement status was analyzed using Fisher's exact test (2).

Variance-type statistic was performed using nonparametric analysis $(6)$. The existence of significance $(P \leq 0.05)$ of BLS ratings among wheat accessions for each experiment and the interaction between wheat accessions and experiments was determined first. To determine whether or not resistance in the 42 wheat accessions differed against each of the two additional strains (BLS Cr25 and BLS Lb74) of $X$. translucens pv. undulosa, a nonparametric analysis $(6,22)$ was performed for ordinal BLS scorings using the MIXED procedure of SAS with the LSMEANS option (Version 9.2, SAS Institute Inc., Cary, NC). Additionally, comparisons were made between individual wheat accessions and between individual bacterial strains. Fixed effects, mean values, median rank $\left(R_{i j}\right)$, relative treatment effects $\left(p_{i j}\right)$, variances, and their $95 \%$ confidence intervals $(\mathrm{CI})$ were calculated using LD_CI macro (6) to determine the significant differences $(P \leq 0.0001)$ between wheat accessions and bacterial strains, and to analyze the interactions between the wheat accessions and the bacterial strains using the MIXED procedure of SAS with the LSMEANS option (Version 9.2, SAS Institute).

\section{Results}

Distribution of BLS resistance in different geographic macroregions. Among the 605 winter wheat accessions evaluated, average BLS scores ranged from 0.9 to 6.0. Of these, $8.3 \%$ showed scores of 0.9 to 2.0 and were rated as resistant (Fig. 1). Among the susceptible accessions, 200 were rated 2.1 to $3.0,243$ were rated 3.1 to 4.0 , and 112 were rated between 4.1 and 6.0 (Fig. 1). Resistant accessions were identified from every macroregion except

Table 1. Responses of winter wheat accessions to Xanthomonas translucens pv. undulosa strain BLSW16 from Casselton, ND evaluated in the greenhouse

\begin{tabular}{lcccc}
\hline & \multicolumn{4}{c}{ Responses of accessions to BLSW16 } \\
\cline { 2 - 5 } Macroregion & Total & \multicolumn{1}{c}{ S } & R & \% $^{\mathbf{y}}$ \\
\hline Northern Africa & 2 & 2 & 0 & $0.0 \mathrm{abc}$ \\
Northern Europe & 43 & 43 & 0 & $0.0 \mathrm{a}$ \\
Eastern Europe & 113 & 109 & 4 & $3.5 \mathrm{a}$ \\
Southern Europe & 69 & 66 & 3 & $4.3 \mathrm{a}$ \\
South-central Asia & 170 & 159 & 11 & $6.5 \mathrm{a}$ \\
Western Europe & 85 & 77 & 8 & $9.4 \mathrm{ab}$ \\
Eastern Asia & 32 & 28 & 4 & $12.5 \mathrm{ab}$ \\
South America & 22 & 19 & 3 & $13.6 \mathrm{ab}$ \\
Western Asia & 26 & 21 & 5 & $19.2 \mathrm{ab}$ \\
Northern America & 35 & 25 & 10 & $28.6 \mathrm{~b}$ \\
Australia-New Zealand & 5 & 3 & 2 & $40.0 \mathrm{abc}$ \\
Total & $602^{\mathbf{z}}$ & 552 & 50 & 8.3 \\
\hline
\end{tabular}

$\mathrm{x}$ Accessions were arranged in randomized complete block design with three replications. Each plastic cone contained three plants. Disease reactions within infiltrated areas on flag leaves were scored between 7 and 10 days after infiltration using a 0 to 6 scale (16). Disease reactions were based on average of nine infiltrated areas on flag leaves (one site on each flag leaf). Disease scores of 0 to 2 or water-soaking less than $10 \%$ were considered resistant (R) (26), and 2.1 to 6 were considered susceptible (S).

${ }^{y}$ In column, percentage of the total wheat accessions from each region that were resistant to bacterial leaf streak and values followed by the same letters are not significantly different $(P \leq 0.05)$ by binomial confidence intervals. $\mathrm{z}$ Three susceptible accessions not included in regions listed in Figure 1. 
northern Africa (only 2 tested) and northern Europe, suggesting that BLS resistance is widely distributed geographically (Table 1). Resistance was significantly $(P \leq 0.05)$ more frequent in accessions from North America (28.6\%) compared to south-central Asia (6.5\%), southern Europe (4.3\%), eastern Europe (3.5\%), and northern Europe (0\%) (Table 1). Based on geographic scale, accessions from Europe had a significantly lower frequency $(P=0.01)$ of BLS resistance (15 of 310 or $4.8 \%$ ) compared to accessions from the Americas (13 of 57 or $22.8 \%$ ). Improvement status "cultivated" was associated with BLS susceptibility $(P=0.05$, whereas improvement status "cultivar" was associated with resistance $(P=$ $0.05)$. There were no significant associations between disease resistance and the landrace or breeding categories.

Reactions of winter wheat accessions to $X$. translucens pv. undulosa strain BLSW16. There were 50 accessions that initially showed resistance to BLS, and many also showed some resistance to other important wheat diseases (Table 2). Four accessions had exceptionally low disease ratings (scores of 1 or less): PI 178184, CItr 11731, PI 583786, and PI 326301. PI 178184 is a landrace accession from eastern Turkey collected in 1948 by J. Harlan. CItr 11731 and PI 583786 are wheat breeding lines from the midwestern United States. PI 326301 is a cultivar developed in the 1960s in Kazakhstan. The highest frequency of resistance to BLS on a country basis occurred among accessions from China, where resistance was found in two accessions (PI 82886 and PI 83248) from Jiangsu Province, one cultivated accession (PI 435113) from Henan Province, and one cultivar (PI 565178) from Hebei Province. Other resistant accessions from Asia included two accessions each from Iran (PI 243759 and PI 243776), Kazakhstan (PI 326301 and PI 572654), Armenia (PI 94374 and PI 591862), and Turkey (PI 172582 and PI 178184) (Table 2).

Wheat accessions from South America varied in their reactions to BLS. Of 22 South American accessions evaluated, two (PI 436469 and Cltr 15942) from Chile and one (PI 351315) from Argentina were resistant to BLS (Table 2). Among the susceptible accessions, 10 were from Chile and the rest were from Cuba, Peru, Uruguay, and Venezuela.

Ten of the accessions (28.6\%) from North America were identified as resistant, including wheat cultivar OAC104 (Cltr 11862) from Ontario, Canada. A high frequency of resistance occurred among accessions from the United States. These accessions were

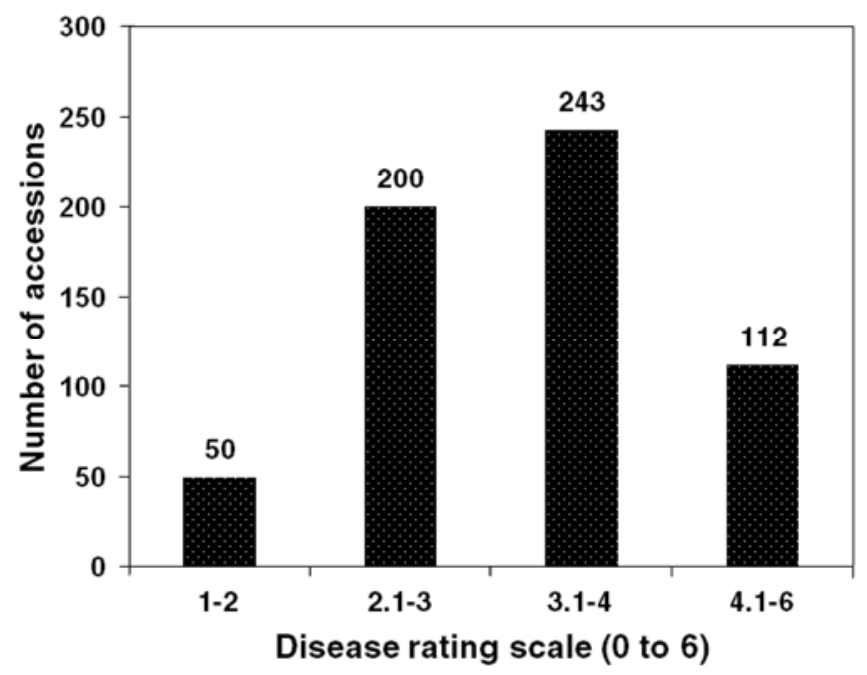

Fig. 1. Frequency of winter wheat accessions $(n=605)$ resistance or susceptibility to Xanthomonas translucens pv. undulosa strain BLSW16 evaluated in the greenhouse, North Dakota. Disease reaction was assessed visually on the flag leaf of each plant between 7 and 10 days after infiltration on a 0 to 6 disease rating scale (16), where $0=$ no visible symptoms, $1=$ chlorosis without water-soaked lesions, $2=$ water-soaking less than $10 \%, 3=$ water-soaking 10 to $30 \%, 4=$ watersoaking 31 to $70 \%, 5=$ water-soaking 71 to $100 \%$, and $6=$ water-soaking extending beyond the infiltrated area. Disease scores of the nine infiltrated areas on flag leaves (one site on each flag leaf) were averaged. mainly breeding lines and cultivars, and originated from Kansas (CItr 11731), Nebraska (CItr 11984), Indiana (CItr 13701), Ohio (CItr 14156), Oregon (PI 565361), Illinois (PI 583672), Oklahoma (PI 583786), and Washington (PI 628640) (Table 2). CItr 11731 was developed by Kansas State University and contributed to the collection in 1935; and PI 583786 originated in Oklahoma, and was derived from a wide cross and has resistance to Wheat streak mosaic virus $(21,25)$.

Inoculation of a subset of the 50 to retest 42 resistant accessions utilizing each of the two additional strains (BLS Cr25 and BLS Lb74) of $X$. translucens pv. undulosa. No significant interaction between wheat accessions and experiment was observed. Thus, combined analysis over the two experiments was performed and disease scores were averaged for each accession. The nonparametric analysis $(6,22)$ revealed that wheat accessions differed significantly $(P \leq 0.0001)$; however, bacterial strains did not have significant effects $(P=0.6355)$ (data not shown). The interactions between wheat accessions and bacterial strains were significant $(P$ $\leq$ 0.0001) (data not shown). Thirty-five wheat accessions had lower median ratings (with a median value of 0 to 2.0), mean rank, and relative marginal effects than the remaining wheat accessions (Table 3). In contrast, one accession (PI 266860) from New Zealand was susceptible to both strains. Six wheat accessions, PI 583786, PI 266142, PI 351338, PI 591862, Cltr 11862, and PI 82886, resistant to BLSW16 showed differential responses to the two additional strains (BLS Cr25 and BLS Lb74) of X. translucens pv. undulosa (Table 3).

\section{Discussion}

Current management strategies to reduce the impact of BLS on wheat production include seed treatment with hot water or chemicals (11-13), and planting resistant cultivars (15). The use of antibiotics to control BLS is not practical due to costs and the risk of developing antibiotic resistance in bacterial populations (14). Therefore, it is imperative to develop resistant wheat varieties for managing BLS. In this study, part of the NSGC core subset of winter wheat accessions was randomly sampled to represent different geographic regions and evaluated in the greenhouse to identify accessions that are resistant to BLS. Accessions with high levels of resistance to multiple strains of $X$. translucens pv. undulosa were identified, and these could be useful sources of resistance in winter wheat breeding programs, particularly the North American breeding lines and cultivars which are more likely to be better adapted to U.S. growing conditions compared to landrace materials from overseas.

In the previous studies, spring wheat cultivars Pavon 76, Mochis T88, Nanjing 8331, and Thornbird were found to be resistant to BLS in Mexico $(8,10)$, while winter wheat cultivars Magnum, Bayles, Sawyer, and Terral 101 showed resistance to BLS in the United States (17). Despite efforts made in the past decade to evaluate and characterize resistance to BLS, the available pool of BLS-resistant wheat appears to be inadequate, and more materials should be evaluated to identify additional sources of resistance to BLS for use in wheat breeding programs.

Disease reactions (0 to 6 rating scale), an indicator of susceptibility or resistance within infiltrated areas on flag leaves, were used to identify resistance in wheat germplasm and to determine variation in virulence in bacterial strains and appeared to be the best at 9 days after infiltration for wheat cultivars and bacterial strains tested $(16,18)$. Furthermore, disease reactions were converted into disease severities such as $0,5,20,50,85$, and $100 \%$ of water-soaking developed within infiltrated areas of flag leaves and were used to evaluate resistance in wheat (16). Although disease reactions within infiltrated sites differed consistently between susceptible and resistant wheat cultivars, disease severities were altered due to differences in inoculum concentrations and environmental factors (16). More importantly, even weakly virulent bacterial strains developed disease symptoms when high inoculum doses and wounded wheat leaves of susceptible cultivars were used and kept at $100 \%$ relative humidity (16). Although field screening 
was effective in identifying resistance to BLS, disease reactions on wheat accessions were confounded by plant phenology and genotype $\times$ environment interactions (26). Thus, we performed experiments in controlled environment conditions, and used stringent criteria such as disease scores of less than 2.0 (i.e., less than $10 \%$ water-soaking and chlorosis symptoms) and relatively high bacterial inoculum dose $\left(10^{7} \mathrm{CFU} / \mathrm{ml}\right)$ for classifying accessions as resistant to BLS between 7 and 10 days after infiltration. Marked differences in disease resistance among accessions were recorded, and this variation in disease reactions is likely due to genetic diver-

Table 2. Responses of the 50 resistant winter wheat accessions to Xanthomonas translucens pv. undulosa strain BLSW16 collected from Casselton, ND, and some other foliar pathogens

\begin{tabular}{|c|c|c|c|c|c|c|}
\hline Accession no. ${ }^{r}$ & Name $^{\mathrm{s}}$ & Region & Country & Status $^{t}$ & $\begin{array}{l}\text { Ave. disease } \\
\text { score }^{\mathrm{u}}\end{array}$ & $\begin{array}{l}\text { Resistance to other } \\
\text { foliar pathogens }\end{array}$ \\
\hline PI 266860 & Aotea & Australia-New Zealand & New Zealand & $\mathrm{C}$ & 1.2 & Stripe rust ${ }^{\mathrm{v}, \mathrm{w}}$ \\
\hline PI 266861 & Arawa & Australia-New Zealand & New Zealand & $\mathrm{C}$ & 2.0 & Stripe rust ${ }^{\mathrm{w}}$, powdery mildew \\
\hline PI 435113 & Ping Yuan 50 & Eastern Asia & China & $\mathrm{Cd}$ & 2.0 & Leaf rust, stripe rustt ${ }^{\mathrm{v}, \mathrm{w}}$ \\
\hline PI 565178 & Shichiazuang 5144 & Eastern Asia & China & $\mathrm{C}$ & 1.4 & $\begin{array}{l}\text { Stripe rust }(4 \text { races })^{\mathrm{v}, \mathrm{x}} \text {, powdery } \\
\text { mildew }\end{array}$ \\
\hline PI 82886 & C5B & Eastern Asia & China & $\mathrm{L}$ & 1.6 & Leaf rust, stripe rust (2 races) $)^{\mathrm{v}, \mathrm{x}}$ \\
\hline PI 83248 & F24 & Eastern Asia & China & $\mathrm{L}$ & 1.4 & Stripe rust $(3 \text { races })^{\mathrm{v}, \mathrm{x}}$ \\
\hline PI 338387 & $\mathrm{C} 48$ & Eastern Europe & Poland & $\mathrm{C}$ & 1.7 & $\begin{array}{l}\text { Stripe rust }(1 \text { race })^{\mathrm{v}, \mathrm{x}} \text {, powdery } \\
\text { mildew }\end{array}$ \\
\hline PI 278423 & Filipescu & Eastern Europe & Romania & $\mathrm{Cd}$ & 1.9 & Stripe rust ${ }^{\mathrm{V}}$ \\
\hline PI 191287 & Tejskaia & Eastern Europe & Russian Federation & $\mathrm{C}$ & 1.7 & BYDV, stripe rust ${ }^{\mathrm{V}}$ \\
\hline PI 351202 & Moskovskaja 02460 & Eastern Europe & Russian Federation & $\mathrm{C}$ & 1.9 & Stripe rust $\mathrm{v}^{\mathrm{v}}$ \\
\hline CItr 11862 & OAC 104 & Northern America & Canada & $\mathrm{C}$ & 2.0 & $\mathrm{NA}^{\mathrm{y}}$ \\
\hline CItr 11731 & Kansas No. 343273 & Northern America & United States & B & 0.9 & BYDV \\
\hline CItr 11984 & Nebr. Sel. 4CS-21 & Northern America & United States & B & 1.4 & Stripe rust ${ }^{\mathrm{v}}$ \\
\hline CItr 13701 & Knox 62 & Northern America & United States & $\mathrm{C}$ & 1.9 & NA \\
\hline CItr 14156 & Logan & Northern America & United States & $\mathrm{C}$ & 2.0 & NA \\
\hline PI 565361 & Prohibition & Northern America & United States & $\mathrm{C}$ & 2.0 & NA \\
\hline PI 583672 & Satanta & Northern America & United States & $\mathrm{C}$ & 1.6 & NA \\
\hline PI 583786 & OK65C93-8 & Northern America & United States & B & 1.0 & Stripe rust $(1 \text { race })^{\mathrm{x}}$ \\
\hline PI 628640 & Finch & Northern America & United States & $\mathrm{C}$ & 2.0 & Stripe rust ${ }^{\mathrm{v}, \mathrm{w}}$ \\
\hline PI 633885 & N02Y5057 & Northern America & United States & B & 1.6 & Stripe rust ${ }^{\mathrm{v}, \mathrm{w}}$ \\
\hline PI 351315 & 38 M.A. & South America & Argentina & $\mathrm{C}$ & 1.3 & NA \\
\hline CItr 15942 & CAR 16 & South America & Chile & B & 1.3 & Stripe rust ${ }^{\mathrm{w}}$ \\
\hline PI 436469 & 447 & South America & Chile & $\mathrm{L}$ & 1.4 & Stripe rust $(2 \text { races })^{\mathrm{x}}$ \\
\hline PI 243759 & 5499 & South-central Asia & Iran & $\mathrm{L}$ & 1.3 & Powdery mildew \\
\hline PI 243774 & 5515 & South-central Asia & Iran & $\mathrm{L}$ & 1.6 & NA \\
\hline PI 243776 & 5519 & South-central Asia & Iran & $\mathrm{L}$ & 1.1 & NA \\
\hline PI 621837 & IWA8609676 & South-central Asia & Iran & $\mathrm{L}$ & 2.0 & Stripe rust $(2 \text { race })^{\mathrm{v}, \mathrm{x}}$ \\
\hline PI 627456 & IWA8602425 & South-central Asia & Iran & $\mathrm{L}$ & 2.0 & NA \\
\hline PI 627521 & IWA8602602 & South-central Asia & Iran & $\mathrm{L}$ & 2.0 & Stripe rust $(5 \text { races })^{\mathrm{v}, \mathrm{w}, \mathrm{x}}$ \\
\hline PI 627649 & IWA8603072 & South-central Asia & Iran & $\mathrm{L}$ & 1.7 & Stripe rust $(1 \text { race })^{x}$ \\
\hline PI 326301 & Alabasskaja & South-central Asia & Kazakhstan & $\mathrm{C}$ & 1.0 & Stripe rust ${ }^{\mathrm{V}}$ \\
\hline PI 572654 & Grekum 3 & South-central Asia & Kazakhstan & $\mathrm{C}$ & 2.0 & Stripe rust ${ }^{\mathrm{v}, \mathrm{w}}$ \\
\hline PI 429689 & NW86A & South-central Asia & Nepal & $\mathrm{L}$ & 1.9 & Stripe rust $(1 \text { race })^{v, w, x}$ \\
\hline PI 565404 & Tadzykskaja 13 & South-central Asia & Tajikistan & $\mathrm{C}$ & 2.0 & NA \\
\hline PI 344545 & Unknown & Southern Europe & Croatia & $\mathrm{Cd}$ & 2.0 & NA \\
\hline PI 266142 & Diamiano Chiesa & Southern Europe & Italy & $\mathrm{C}$ & 1.7 & Leaf rust, stripe rust $(1 \text { race })^{x}$ \\
\hline PI 345476 & 473 & Southern Europe & Serbia & $\mathrm{L}$ & 1.6 & Stripe rust $^{\mathrm{V}}$ \\
\hline PI 591862 & Artashati 42 & Western Asia & Armenia & $\mathrm{C}$ & 2.0 & Stripe rust $\mathrm{v}, \mathrm{w}$ \\
\hline PI 94374 & $65 \mathrm{BSR}$ & Western Asia & Armenia & $\mathrm{L}$ & 2.0 & Stripe rust $(2 \text { races })^{\mathrm{v}, \mathrm{x}}$ \\
\hline PI 57185 & CI 7132 & Western Asia & Georgia & $\mathrm{L}$ & 1.5 & NA \\
\hline PI 172582 & 8728 & Western Asia & Turkey & $\mathrm{L}$ & 1.3 & Stripe rust $(1 \text { race })^{x}$, snow mold ${ }^{z}$ \\
\hline PI 178184 & Tir & Western Asia & Turkey & $\mathrm{L}$ & 0.8 & NA \\
\hline PI 351046 & $69 \mathrm{Z} 2.179 / 1380 \mathrm{C}$ & Western Europe & Austria & $\mathrm{L}$ & 2.0 & Stripe rust ${ }^{\mathrm{v}}$ \\
\hline PI 338358 & CAMA & Western Europe & Belgium & $\mathrm{C}$ & 1.6 & Stripe rust $(3 \text { races })^{x}$ \\
\hline PI 340685 & Coutiches & Western Europe & France & $\mathrm{C}$ & 2.0 & Stripe rust ${ }^{\mathrm{v}, \mathrm{w}}$ \\
\hline PI 351314 & Hybride de la Noue & Western Europe & France & $\mathrm{C}$ & 2.0 & Stripe rust $(3 \text { races })^{\mathrm{v}, \mathrm{w}, \mathrm{x}}$ \\
\hline PI 278249 & Ostmarker & Western Europe & Germany & $\mathrm{L}$ & 2.0 & Stripe rust ${ }^{\mathrm{v}, \mathrm{w}}$ \\
\hline PI 285939 & Dornburger Heils Dickhopf & Western Europe & Germany & $\mathrm{C}$ & 2.0 & Stripe rust ${ }^{\mathrm{v}}$ \\
\hline PI 351338 & K43 Kienles & Western Europe & Germany & B & 1.6 & Stripe rust ${ }^{\mathrm{v}, \mathrm{w}}$ \\
\hline PI 350974 & 69Z2.104/672A & Western Europe & Switzerland & $\mathrm{L}$ & 1.5 & Stripe rust ${ }^{\mathrm{v}, \mathrm{w}}$ \\
\hline
\end{tabular}

${ }^{\mathrm{r}}$ Winter wheat accession number in USDA National Small Grains Collection, Aberdeen, ID. Data on some other foliar pathogens were retrieved from the GRIN database (http://www.ars-grin.gov/npgs/verified 17 June 2009).

${ }^{\mathrm{s}}$ Entry name for winter wheat accessions in USDA National Small Grains Collection.

${ }^{\mathrm{t}} \mathrm{IS}=$ improvement status, $\mathrm{B}=$ breeding line, $\mathrm{C}=$ cultivar, $\mathrm{Cd}=$ cultivated, and $\mathrm{L}=$ landrace. Accessions were arranged in randomized complete block design with three replications. Each plastic cone contained three plants (total nine plants per accession).

" Disease reactions within infiltrated areas were scored between 7 and 10 days after infiltration using a 0 to 6 scale $(16)$, where $0=$ no visible symptoms, $1=$ chlorosis without water-soaked lesions, $2=$ water-soaking less than $10 \%, 3=$ water-soaking 10 to $30 \%, 4=$ water-soaking 31 to $70 \%, 5=$ water-soaking 71 to $100 \%$, and $6=$ water-soaking extending beyond infiltrated area. Disease reactions of the nine infiltrated areas on flag leaves (one site on each flag leaf) were averaged. Disease scores of 0 to 2 or water-soaking less than $10 \%$ were considered resistant (R) (26), and 2.1 to 6 were considered susceptible (S).

${ }^{\mathrm{v}}$ Resistant in the field at adult plant stage at Mount Vernon.

${ }^{w}$ Resistant in the field at adult plant stage at Pullman.

${ }^{x}$ Resistant at seedling stage to specific races of the stripe rust pathogen.

${ }^{\mathrm{y}} \mathrm{NA}=$ data were not available for other foliar pathogens.

${ }^{\mathrm{z}}$ Bruehl (5). 
sity among wheat accessions tested. The resistant accessions identified in this study have not been reported previously $(10,15,18,26)$ and may represent novel sources of resistance to $X$. translucens pv. undulosa.

Landrace accessions in the NSGC were originally collected from farmers' fields or markets either before the era of modern plant breeding or later in less favorable environments where modern cultivars are not grown (2). No significant association between landrace status and BLS resistance was observed. Improvement status "cultivated" is used when it is uncertain if the accession is a landrace or cultivar (2), and in the present study classification as cultivated was associated with BLS susceptibility. However, BLS resistance was significantly associated with accessions classified as cultivars, which were all presumably developed by wheat breeding programs. Since many of these materials were from North America, this result may indicate that breeding programs in the United States have made some progress toward BLS resistance simply by selecting in a disease conducive environment. The identified resistant cultivars and breeding lines should also possess other good agronomic traits relative to landrace accessions. Perhaps they can be used directly as parents in wheat breeding programs for developing wheat varieties resistant to $X$. translucens pv. undulosa.

In this study, resistance differences among wheat accessions were evident when 42 BLS-resistant accessions were further assessed with each of the two additional BLS strains from different geographic origins. Among these, 35 winter wheat accessions were resistant to all three strains and seven accessions were resistant to either one or two strains. This result demonstrates that strains of $X$.

Table 3. Median, mean rank $\left(R_{i j}\right)$, and relative treatment effects $\left(p_{i j}\right)$ along $95 \%$ confidence intervals (CI) relative treatment effects for bacterial leaf streak (BLS) ratings on the 42 resistant winter wheat accessions randomly selected and retested with the two additional strains (BLS Cr25 and BLS Lb74) of Xanthomonas translucens pv. undulosa from Carrington and Lisbon, ND, respectively

\begin{tabular}{|c|c|c|c|c|c|c|c|c|}
\hline \multirow[b]{2}{*}{$\operatorname{ACPNO}^{x}$} & \multicolumn{4}{|c|}{ BLS Cr 25} & \multicolumn{4}{|c|}{ BLS Lb 74} \\
\hline & Mediany $^{y}$ & $\boldsymbol{R}_{i j}$ & $\hat{p}_{i j}$ & $95 \%$ CI for $p_{i j}$ & Median & $\boldsymbol{R}_{i j}$ & $\hat{p}_{i j}$ & $95 \%$ CI for $p_{i j}$ \\
\hline PI 344545 & 1 & 322.6 & 0.3 & $(0.260,0.572)^{\mathrm{z}}$ & 0 & 77.70 & 0.1 & $(0.054,0.170)$ \\
\hline PI 278423 & 1 & 261.7 & 0.3 & $(0.161,0.558)$ & 1 & 218.3 & 0.2 & $(0.150,0.449)$ \\
\hline PI 350974 & 1 & 322.6 & 0.3 & $(0.260,0.572)$ & 1 & 186.7 & 0.2 & $(0.127,0.394)$ \\
\hline PI 435113 & 1 & 92.9 & 0.1 & $(0.069,0.190)$ & 2 & 623.4 & 0.7 & $(0.662,0.872)$ \\
\hline Cltr 11984 & 1 & 280.4 & 0.3 & $(0.229,0.501)$ & 2 & 417.6 & 0.4 & $(0.395,0.654)$ \\
\hline PI 172582 & 1 & 244.0 & 0.3 & $(0.169,0.492)$ & 2 & 449.2 & 0.5 & $(0.456,0.670)$ \\
\hline PI 351202 & 1 & 300.2 & 0.3 & $(0.205,0.589)$ & 2 & 417.6 & 0.4 & $(0.395,0.654)$ \\
\hline PI 351314 & 1 & 218.3 & 0.2 & $(0.150,0.449)$ & 2 & 390.7 & 0.4 & $(0.390,0.595)$ \\
\hline PI 583672 & 1 & 354.0 & 0.4 & $(0.229,0.686)$ & 2 & 534.7 & 0.6 & $(0.568,0.764)$ \\
\hline Cltr 13701 & 2 & 471.3 & 0.5 & $(0.422,0.745)$ & 1 & 264.0 & 0.3 & $(0.227,0.458)$ \\
\hline Cltr 14156 & 2 & 511.1 & 0.5 & $(0.485,0.776)$ & 1 & 232.3 & 0.2 & $(0.200,0.406)$ \\
\hline PI 94374 & 2 & 439.7 & 0.5 & $(0.368,0.725)$ & 1 & 295.7 & 0.3 & $(0.259,0.501)$ \\
\hline PI 178184 & 2 & 439.7 & 0.5 & $(0.368,0.725)$ & 1 & 217.1 & 0.2 & $(0.173,0.403)$ \\
\hline PI 243759 & 2 & 385.9 & 0.4 & $(0.344,0.631)$ & 1 & 232.3 & 0.2 & $(0.200,0.406)$ \\
\hline PI 243776 & 2 & 377.6 & 0.4 & $(0.264,0.696)$ & 1 & 171.4 & 0.2 & $(0.107,0.388)$ \\
\hline PI 338358 & 2 & 374.0 & 0.4 & $(0.278,0.673)$ & 1 & 155.0 & 0.2 & $(0.110,0.324)$ \\
\hline PI 338387 & 2 & 444.4 & 0.5 & $(0.406,0.703)$ & 1 & 307.3 & 0.3 & $(0.232,0.570)$ \\
\hline PI 429689 & 2 & 534.7 & 0.6 & $(0.568,0.764)$ & 1 & 334.2 & 0.4 & $(0.241,0.625)$ \\
\hline Cltr 11731 & 2 & 444.4 & 0.5 & $(0.406,0.703)$ & 2 & 476.1 & 0.5 & $(0.468,0.718)$ \\
\hline Cltr 15942 & 2 & 479.4 & 0.5 & $(0.422,0.761)$ & 2 & 296.9 & 0.3 & $(0.234,0.539)$ \\
\hline PI 57185 & 2 & 449.2 & 0.5 & $(0.456,0.670)$ & 2 & 417.6 & 0.4 & $(0.395,0.654)$ \\
\hline PI 83248 & 2 & 390.7 & 0.4 & $(0.390,0.595)$ & 2 & 385.9 & 0.4 & $(0.344,0.631)$ \\
\hline PI 266861 & 2 & 354.2 & 0.4 & $(0.299,0.603)$ & 2 & 354.2 & 0.4 & $(0.299,0.603)$ \\
\hline PI 278249 & 2 & 296.9 & 0.3 & $(0.234,0.539)$ & 2 & 312.1 & 0.3 & $(0.263,0.540)$ \\
\hline PI 285939 & 2 & 449.0 & 0.5 & $(0.348,0.760)$ & 2 & 296.9 & 0.3 & $(0.234,0.539)$ \\
\hline PI 326301 & 2 & 354.2 & 0.4 & $(0.299,0.603)$ & 2 & 370.7 & 0.4 & $(0.309,0.632)$ \\
\hline PI 340685 & 2 & 327.3 & 0.3 & $(0.297,0.539)$ & 2 & 370.7 & 0.4 & $(0.309,0.632)$ \\
\hline PI 345476 & 2 & 460.9 & 0.5 & $(0.420,0.725)$ & 2 & 281.7 & 0.3 & $(0.207,0.537)$ \\
\hline PI 351046 & 2 & 400.9 & 0.4 & $(0.292,0.716)$ & 2 & 385.9 & 0.4 & $(0.344,0.631)$ \\
\hline PI 351315 & 2 & 359.0 & 0.4 & $(0.340,0.570)$ & 2 & 449.2 & 0.5 & $(0.456,0.670)$ \\
\hline PI 436469 & 2 & 343.8 & 0.4 & $(0.302,0.574)$ & 2 & 507.8 & 0.5 & $(0.548,0.723)$ \\
\hline PI 565178 & 2 & 483.0 & 0.5 & $(0.400,0.783)$ & 2 & 561.6 & 0.6 & $(0.594,0.800)$ \\
\hline PI 565361 & 2 & 422.3 & 0.5 & $(0.452,0.610)$ & 2 & 507.8 & 0.5 & $(0.548,0.723)$ \\
\hline PI 565404 & 2 & 390.7 & 0.4 & $(0.390,0.595)$ & 2 & 359.0 & 0.4 & $(0.340,0.570)$ \\
\hline PI 572654 & 2 & 359.0 & 0.4 & $(0.340,0.570)$ & 2 & 422.3 & 0.5 & $(0.452,0.610)$ \\
\hline PI 583786 & 1 & 248.8 & 0.3 & $(0.199,0.456)$ & 3 & 615.3 & 0.7 & $(0.661,0.859)$ \\
\hline PI 266142 & 2 & 354.2 & 0.4 & $(0.299,0.603)$ & 3 & 596.6 & 0.6 & $(0.624,0.846)$ \\
\hline PI 351338 & 2 & 561.6 & 0.6 & $(0.594,0.800)$ & 3 & 679.1 & 0.7 & $(0.766,0.915)$ \\
\hline PI 591862 & 2 & 417.6 & 0.4 & $(0.395,0.654)$ & 3 & 601.8 & 0.6 & $(0.559,0.885)$ \\
\hline Cltr 11862 & 3 & 588.4 & 0.6 & $(0.624,0.832)$ & 2 & 449.2 & 0.5 & $(0.456,0.670)$ \\
\hline PI 82886 & 3 & 601.8 & 0.6 & $(0.559,0.885)$ & 2 & 370.7 & 0.4 & $(0.309,0.632)$ \\
\hline PI 266860 & 3 & 685.3 & 0.7 & $(0.769,0.923)$ & 3 & 615.3 & 0.7 & $(0.661,0.859)$ \\
\hline $\begin{array}{l}\text { Magnum } \\
\text { (Resistant check) }\end{array}$ & 1 & 200.7 & 0.2 & $(0.182,0.340)$ & 2 & 327.3 & 0.3 & $(0.297,0.539)$ \\
\hline $\begin{array}{l}\text { ND } 495 \\
\text { (Susceptible check) }\end{array}$ & 4 & 776.6 & 0.8 & $(0.970,0.985)$ & 5 & 780.3 & 0.8 & $(0.975,0.989)$ \\
\hline
\end{tabular}

${ }^{x}$ Accessions number in USDA National Small Grains Collection, Aberdeen, ID.

${ }^{y}$ In each experiment, disease scores of the nine infiltrated areas on flag leaves (one site on each flag leaf) were averaged. Accessions were arranged in randomized complete block design with three replications. Each plastic cone was considered a replication and contained three plants. Two independent experiments were conducted in the greenhouse. Disease ratings were recorded visually on the flag leaf of each plant between 7 and 10 days after infiltration on an ordinal 0 to 6 rating scale (16), where $0=$ no visible symptoms, $1=$ chlorosis without water-soaked lesions, $2=$ water-soaking less than $10 \%, 3=$ water-soaking 10 to $30 \%, 4=$ water-soaking 31 to $70 \%, 5=$ water-soaking 71 to $100 \%$, and $6=$ water-soaking extending beyond the infiltrated area Median, $R_{i j}, p_{i j}$, and CI values were estimated (6,22). Median value less than 2 was resistant and above 2 was susceptible.

${ }^{\mathrm{z}}$ First and second values in parentheses indicate lower limit and upper limit at $95 \%$ CI, respectively (6). 
translucens pv. undulosa interact differently with wheat accessions. Thus, selection of strains can significantly affect the reactions of wheat germplasm to X. translucens pv. undulosa, and the same sources of resistance in winter wheat to $X$. translucens $p v$. undulosa may be ineffective against predominant virulent strains present in different wheat-growing regions of the United States. The best winter wheat accessions could be those that have the relatively lowest BLS ratings or median values. It appears that the best winter wheat accessions for breeding programs could be identified by combining the results from evaluation of wheat accessions individually inoculated with a set of BLS strains and comparing the median values. Alternatively, the use of an inoculum mixture with high concentration $\left(10^{7} \mathrm{CFU} / \mathrm{ml}\right)$ of virulent strains of $X$. translucens pv. undulosa from different geographic areas or with known genetic differences may lead to the development of winter wheat cultivars with improved resistance to $X$. translucens pv. undulosa.

It has been suggested that identifying BLS-resistant wheat varieties has been hampered because resistance to this disease is incomplete (8), and presumably is governed by quantitative trait loci (10). Field experiments conducted in Mexico indicated that BLS resistance in five wheat cultivars (Turaco, Alondra, Angostura, Mochis, and Pavon 76) is governed by five genes: Bls1/blsl, Bls2/bls2, Bls3/bls3, Bls4/bls4, and Bls5/bls5 (10,11). Among these five genes, $B l s 1$ is present in wheat cultivars Angostura, Mochis, and Pavon 76 (10). Although there were significant differences in the levels of resistance of the wheat accessions against three bacterial strains used in this study, further studies related to the inheritance of resistance to $X$. translucens pv. undulosa in these accessions, including allelism relationships, are necessary to test if these accessions have the same genes as reported earlier $(10,15)$ or if they contain a novel gene(s).

The disease significantly reduces grain yield and quality of both spring and winter wheat. Yield loss due to BLS was estimated as high as 30 to $40 \%$ in sprinkler irrigated fields in Idaho (12). Both kernel weight and plumpness were severely affected and negatively correlated with BLS severity on the flag leaf of wheat and barley (23). In Mexico, single tiller studies revealed that 11 to $29 \%$ of grain weight per spike was lost when $50 \%$ of the flag leaf was affected by the disease (9). BLS has been re-emerging as a potential threat to wheat production, particularly in the Northern Great Plains of the United States. This may be due to lack of effective management tools. Crop rotation, seed certification, seed treatments, bactericides, and host resistance have been investigated in the past decades $(7,9,11,13,15,18,26)$. Although these disease management tactics have shown some promise, an adequate control of BLS has not been provided for wheat producers. Some of the accessions identified in this study may have useful resistance to $X$. translucens pv. undulosa and may be a key component of integrated disease management. Deploying wheat varieties with resistance to BLS would not only curtail local carryover of bacteria in seed and regional movement of this seedborne pathogen through exchange of wheat germplasm, but also could reduce yield losses due to the disease.

Among the 50 BLS-resistant accessions, the majority (70\%) were resistant to multiple races of stripe rust (Table 2). Four accessions (PI 266861, PI 565178, PI 243759, and PI 338387) were resistant to powdery mildew in addition to some races of stripe rust. Three accessions (PI 82886, PI 83248, and PI 435113) from China were resistant to leaf rust and stem rust. Only one accession (PI 191287) was resistant to both BYDV and stripe rust. One accession (PI 172582) was found previously to be resistant to snow mold (5). Thus, these accessions are likely to carry some other foliar disease resistances useful to wheat breeding programs.

In conclusion, we have used intense disease evaluation methods (e.g., high inoculum dose of multiple virulent strains collected from different geographic areas, stringent disease rating criteria on the flag leaf, and a conducive environment for BLS development) in the greenhouse, and identified potentially diverse BLS-resistant winter wheat germplasm. These panels of genetic resources will provide stable resistance to BLS when different sources are com- bined and utilized in winter wheat breeding programs. Importantly, several BLS-resistant accessions also possessed resistance to multiple diseases such as BYDV, leaf rust, powdery mildew, snow mold (5), Wheat streak mosaic virus $(21,25)$, and different races of stripe rust; and thus, these might be useful to combine resistance genes into an adapted winter wheat cultivar to achieve broad-spectrum resistance to multiple pathogens in wheat.

\section{Acknowledgments}

We gratefully acknowledge financial support for this project from the Wheat Research and Promotion Council, Minnesota, North Dakota Wheat Commission, and State Board of Agricultural Research and Education, North Dakota. We thank Kamal Thapa and Jaimin Patel for technical support. We are grateful to the following scientists for generating the NSGC disease resistance accession data analyzed in this study: Merle G. Eversmeyer, USDA-ARS, retired, for leaf rust data; Roland F. Line, USDA-ARS, retired, and Xianming Chen, USDA-ARS, for stripe rust data; and Steve Leath, USDA-ARS, retired, for powdery mildew data.

\section{Literature Cited}

1. Adhikari, T. B., Gurung, S., Bonman, J., Mergoum, M., Ali, S., and Singh, P. 2009. Assessing resistance in wheat to Xanthomonas translucens pv. undulosa. (Abstr.) Phytopathology 99:S2.

2. Bonman, J. M., Bockelman, B. J., Goates, B. J., Obert, D. E., McGuire, P. E., Qualset, C. O., and Hijmans, R. J. 2006. Geographic distribution of common and dwarf bunt resistance in landraces of Triticum aestivum subsp. aestivum. Crop Sci. 46:1622-1629.

3. Bragard, C., Singer, E., Alizadeh, A., Vauterin, L., Maraite, H., and Swings, J. 1997. Xanthomonas translucens from small grains: Diversity and phytopathological relevance. Phytopathology 87:1111-1117.

4. Broadfoot, W. C., and Robertson, H. T. 1993. Pseudo-black chaff of reward wheat. Sci. Agric. 13:512-514

5. Bruehl, G. W. 1982. Developing wheats resistant to snow mold in Washington State. Plant Dis. 66:1090-1095.

6. Brunner, E., and Puri, M. L. 2001. Nonparametric methods in factorial designs. Stat. Pap. 42:1-52.

7. Cunfer, B. M. 1987. Bacterial and fungal blights of foliage and heads of wheat. Pages 528-541 in: Wheat and Wheat Improvement. 2nd ed. E. G Heynes, ed. ASA, Madison, WI.

8. Duveiller, E. 1990. Screening criteria for bacterial leaf streak in bread wheat, durum wheat and triticale in CIMMYT. Pages 1011-1016 in: Proc. 7th Int. Conf. Plant Pathogenic Bacteria, Vol. 2. Z. Klement, ed. Akademiai Kiado, Budapest.

9. Duveiller, E., and Maraite, H. 1993. Study on yield loss due to Xanthomonas campestris pv. undulosa in wheat under high rainfall temperature conditions. J. Plant Dis. Prot. 100:453-459.

10. Duveiller, E., van Ginkel, M. V., and Thijissen, M. 1993. Genetic analysis of resistance to bacterial leaf streak caused by Xanthomonas campestris pv. undulosa in bread wheat. Euphytica 66:35-43.

11. Forster, R. L., and Schaad, N. W. 1985. Evaluation of seed treatments for eradication of Xanthomonas campestris pv. translucens from wheat seed. (Abstr.) Phytopathology 75:1385.

12. Forster, R. L., and Schaad, N. W. 1988. Control of black chaff of wheat with seed treatment and a foundation seed health program. Plant Dis. 72:935 938.

13. Fourest, E., Rehms, L. D., Sands, D. C., Bjarko, M., and Lund, R. E. 1990. Eradication of Xanthomonas campestris pv. translucens from barley seed with dry heat treatments. Plant Dis. 74:816-818.

14. Levy, S. B. 1998. The challenge of antibiotic resistance. Sci. Am. 278:4653.

15. Maraite, H., Bragard, C., and Duveiller, E. 2007. The status of resistance to bacterial diseases of wheat. Pages 37-49 in: Wheat Production in Stressed Environments. H. T. Buck, J. E. Nisi, and N. Salomon, eds. Springer, New York.

16. Milus, E. A., and Chalkley, D. B. 1994. Virulence of Xanthomonas campestris pv. translucens on selected wheat cultivars. Plant Dis. 78:612-615.

17. Milus, E. A., Duveiller, E., Kirkpatrick, T. L., and Chalkley, D. B. 1996 Relationships between disease reactions under controlled conditions and severity of wheat bacterial streak in the field. Plant Dis. 80:726-730.

18. Milus, E. A., and Mirlohi, A. F. 1994. Use of disease reactions to identify resistance in wheat to bacterial streak. Plant Dis. 78:157-161.

19. Milus, E. A., and Mirlohi, A. F. 1995. Survival of Xanthomonas campestris pv. translucens between successive wheat crops in Arkansas. Plant Dis. 79:263-265.

20. Ou, S. H. 1985. Rice Diseases. Commonwealth Mycological Institute, Kew, Surrey, UK.

21. Sebesta, E. E., Young, H. C., Jr., Porter, D. R., and Webster, J. R. 1995 Registration of two wheat streak mosaic virus resistant wheat germplasms Crop Sci. 35:1238.

22. Shah, D. A., and Madden, L. V. 2004. Nonparametric analysis of ordinal data in designed factorial experiments. Phytopathology 94:33-43.

23. Shane, W. W., Bauer, J. S., and Teng, P. S. 1987. Crop losses caused Xanthomonas streak on spring wheat and barley. Plant Dis. 71:927-930. 
24. Smith, E. F., Jones, L. R., and Reddy, C. S. 1919. The black chaff of wheat. Science 50:48

25. Stoddard, S. L., Lommel, S. A., and Gill, B. S. 1987. Evaluation of wheat germ plasm for resistance to wheat streak mosaic virus by symptomatology, ELISA, and slot-blot hybridization. Plant Dis. 71:714-719.

26. Tillman, B. L., Harrison, S. A., Clark, C. A., Milus, E. A., and Russin, J. S. 1996. Evaluation of bread wheat germplasm for resistance to bacterial streak. Crop Sci. 36:1063-1068.
27. United Nations. 2000. World macroregions and components. Published online. http://millenniumindicators.un.org/unsd/methods/m49/m49regin. htm.

28. United States Department of Agriculture (USDA). 2007. National agricultural statistics, USDA. Published online. http://www.nass.usda.gov (verified 21 May 2008).

29. Zadoks, J. C., Chang, T. T., and Konzak, C. F. 1974. A decimal code for the growth stages of cereals. Weed Res. 14:415-421. 